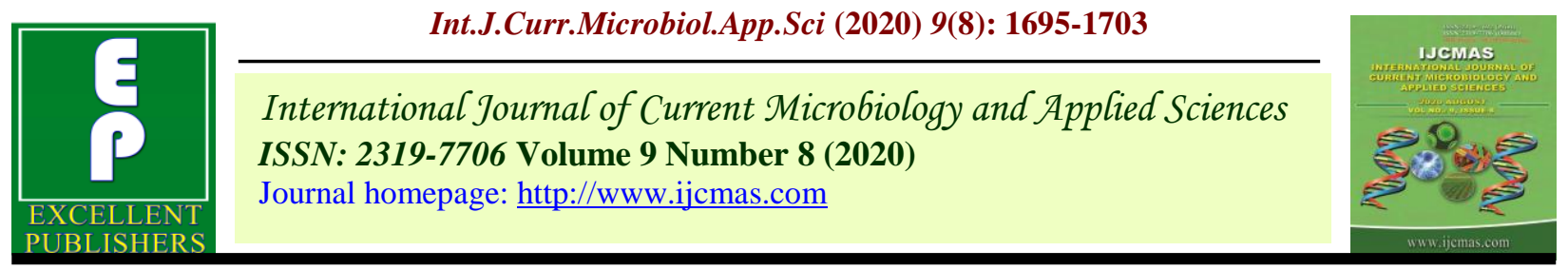

Original Research Article

https://doi.org/10.20546/ijcmas.2020.908.195

\title{
Effect of Various Factors on Hematology and Serum Biochemistry Values of Aseel and Kadaknath Chicken
}

\author{
M. Shanmathy", J. S. Tyagi, M. Gopi, J. Mohan and P. Beulah
}

Division of Avian Physiology and Reproduction, ICAR-Central Avian Research Institute,
Izatnagar- $243122(U P)$, India
*Corresponding author

A B S T R A C T

\section{Keywords}

Hematology, Aseel,

Kadaknath, Age,

Sex, Season, Serum

biochemistry

Article Info

Accepted:

18 July 2020

Available Online:

10 August 2020

\begin{abstract}
The study was conducted to record baseline data for two indigenous breeds of Aseel and Kadaknath and evaluate the effects of Age, sex season and rearing effects on the various hemato-biochemical parameters. For haemoglobin Aseel and Kadaknath recorded values of $11.92 \pm 0.21$ and $13.26 \pm 0.61$ for 3 and 6 week and $12.48 \pm 0.15$ and $12.59 \pm 0.20$ for $9^{\text {th }}$ and $12^{\text {th }}$ week. Highest value for MCHC was recorded by Aseel male during hot -humid season as $89.07 \pm 0.86$ in $3^{\text {rd }}$ week and lowest value was recorded as $52.21 \pm 0.29$ by Aseel male cage in $9^{\text {th }}$ week during winter. The ALT and AST contents were only affected $(\mathrm{P}<0.05)$ by season wherein these were noticed higher during winter season. Biochemical profile revealed that cholesterol and creatinine were higher $(\mathrm{P}<0.05)$ in Aseel birds during winter season.Total protein level was noticed to be affected $(\mathrm{P}<0.05)$ by age and season.
\end{abstract}

\section{Introduction}

India is home to many Indigeneous breeds of fowls that have their own characteristics. Indigeneous birds are known to be hardy and adjust to poor management and feeding. Rural poultry is an important sub sector of poultry production in developing countries (Hussain et al, 2018). The present research work was aimed to evaluate the effect of season, age, breed, sex and rearing system in Aseel and Kadaknath under hot-humid and winter season on their hemato-biochemical responses. Yahav and Hurwitz (1996) have described decreased haematocrit values in fattened broilers in connection with a 24-hour exposure to $36 \pm 1{ }^{\circ} \mathrm{C}$ early in life. Packed cell volume (PCV), haemoglobin $(\mathrm{Hb})$ and total protein values are important haematological parameters, which are of importance in the assessment of health status and disease of birds (Hawkey et al., 1983, 1984). These are good indices of livestock adaptability to prevailing environmental conditions (Kaushish et al., 1976). By evaluating the haematological profile during the seasonal variations, the confusion with disease associated changes can be avoided (Olayemi and Arowolo, 2009). Determination of haematological parameters is a reliable tool 
since it gives specific indication of the ongoing events in the body, serving as an aid to diagnosis and health status assessment (Tibbo et al., 2008). Cold temperature, increased oxygen requirement, cardiac output, and blood flow may result in increased pulmonary arterial pressure overload on the right ventricle (Julian et al., 1989).

\section{Materials and Methods}

\section{Experimental birds and protocol design}

400 eggs of each breed (Aseel peela and Kadaknath) were incubated at Experimental Hatchery Unit of the institute. Day old chicks (sexed by Japanese method of vent sexing) were reared for a period of 12 weeks in two seasons i.e. hot -humid (27.7.201624.10.2016) and winter season 15.12.20169.3.2017. All the birds were maintained under standard managemental conditions under deep litter/cage system with feed and water ad libitum. Birds were offered standard feed.

\section{Equipments}

Setter and hatcher (Dayal poultry appliances, Delhi, India), micropipettes (Eppendorf AG, Germany), table top refrigerated microcentrifuge, (3500 Kubota Corporation, Tokyo, Japan), Abacus vet junior hematoanalyser, ELISA reader Spectra max 190.

\section{Glass and plastic wares}

Glass wares i.e. beaker, test tubes, cylinders, conical flasks, round bottom flasks etc. used throughout the experiment were procured from Borosil, India. Plastic wares viz. flat caps, micro centrifuge tubes $(0.2 \mathrm{ml}, 1.5 \mathrm{ml}$ and $2 \mathrm{ml})$ and tips $(20 \mu \mathrm{l}, 200 \mu \mathrm{l}$ and $1 \mathrm{ml})$ were procured from Axygen, USA. Conical centrifuge tubes $(15 \mathrm{ml}$ and $50 \mathrm{ml})$ were purchased from TarsonPvt. Ltd. India.

\section{Chemicals and kits}

Abacus reagents for Abacus hematoloanalyzer (diatro cleaner vet 5, diatro rinse, diatro lyse, diatro diluent) and Span diagnostic limited, Surat, India diagnostic kits for biochemistry (glucose, total protein, Creatinine, uric acid, cholesterol, ALT and AST.

\section{Sample analysis}

Whole blood $(2 \mathrm{ml})$ collection was collected from jugular vein of randomly selected 50 birds from each breed in each season into sterile vials with and without EDTA as an anticoagulant for haematological and biochemical analysis, respectively. The haematological parameters were estimated manually as well as by Abacus junior vet 5 haemo-analyser (Datron, Ltd.). Blood samples were centrifuged briefly at $1000 \mathrm{rpm}$ for 10 min and supernatant, the serum was decanted and deep frozen $\left(-20^{\circ} \mathrm{C}\right)$ till analysis. Serum samples were analysed using commercial standard diagnostic kits (Span diagnostic limited, Surat, India) using protocol as mentioned on kits

\section{Statistical analysis}

All the generated experimental data was analyzed statistically using SPSS 20.0 (Incl. Chicago) and values were expressed as Mean \pm SE. Factorial $2 \times 2 X 2$ and $2 \times 2 X 2 X 2$ design was used. Values were considered at probability of $5 \%$ and $1 \%$ level as significant and highly significant, respectively.

\section{Results and Discussion}

\section{Hematology (Table 1 and 2)}

\section{Total red blood cell count $\left(\mathrm{TRBC}, \mathbf{1 0}^{6} / \mu \mathrm{l}\right)$}

TRBC count was significantly affected by breed. Kadaknath recorded higher values than 
Aseel which is in agreement with finding of (Pandian et al., 2012) who reported values of 2.96 and 2.82 for Kadaknath and Aseel. RBC count was higher in hot-humid than in winter Decreased erythropoiesis due to stress low feed consumption reduces the number of circulating erythrocyte (Donkoh, 1989).

\section{Haemoglobin (g/dl)}

Significant difference was observed in haemoglobin between the two seasons. Pampori and Iqbal (2007) reported haemoglobin of female and male adult native chickens of Kashmir as $11.32 \pm 0.19 \mathrm{~g} \%$ and $13.21 \pm 0.39 \mathrm{~g} \%$. Tyagi et al., (2007) reported that haemoglobin of broiler chicks at $6^{\text {th }}$ and $8^{\text {th }}$ weeks of age at $23^{\circ} \mathrm{C}$ were 7.63 and 7.70 $\mathrm{g} / \mathrm{dl}$. Lower hemoglobin levels in winter in present study are in agreement to the finding of Pandian et al., (2012).

\section{Packed cell volume (PCV \%)}

Older birds ( 9 and 12 weeks) recorded higher values than younger age groups which is in agreement with Islam et al., (2004). Addas et al (2012) reported PCV values for days 60, 74 and 104 age groups as $(18.60 \pm 0.76 \%)$, $(22.30 \pm 0.76 \%)$ and $(21.20 \pm 0.76 \%)$ respectively. Pandian et al., (2012) reported PCV of Kadakanath as (25.16 \pm 1.53$)$, Nicobari $(28.33 \pm 1.14)$ and Aseel $(30.16 \pm 1.81)$ during Hot-humid $\left(38^{\circ} \mathrm{C}\right)$. Tibetan chickens reared at high altitude had higher haematocrit than chickens reared at low altitude.

\section{Mean cell volume (MCV,fl)}

Results of this experiment are in agreement with the finding of Panigrahy et al., (2017) that $\mathrm{MCV}$ and $\mathrm{MCH}$ were significantly $(p<0.05)$ higher in females and Effect of season was observed in MCV and $\mathrm{MCH}$ but in contrary to reporting of Kundu et al.,
(2015) who found MCV values in males were significantly higher than that in females. Zhang et al., (2007) studied blood Characteristics for High Altitude Adaptation in Tibetan Chickens and reported MCV values of $139.7 \pm 2.29 \mu \mathrm{m}^{3}$ in Tibetan chicken.

Mean corpuscular haemoglobin (MCH, pg).

$\mathrm{MCH}$ reduced in 6 week old chicken which is in agreement with findings of Islam et al., (2004) who studied haematological parameters of native chicken of Bangladesh and reported that $\mathrm{MCH}$ decreases gradually with the advancement of age. Ladokun et al., (2008) found no significant difference between $\mathrm{MCH}$ values in Nigerian chickens and normal feathered chicken and reported their values as $27.20 \mathrm{fl}$ and $28.90 \mathrm{fl}$ respectively.

\section{Mean corpuscular haemoglobin concentration (MCHC, g/dl)}

Rearing system significantly affected MCHC values. Addas et al., (2012) reported significant $(\mathrm{P}<0.01)$ effect of management system for MCHC intensively kept chickens produced higher values $(17.52 \pm 0.30 \mathrm{~g} / \mathrm{dL})$ than the semi - intensively kept chickens $(15.82 \pm 0.30 \mathrm{~g} / \mathrm{dL})$. But in contrast to the above, birds in deep litter produced higher values as compared to birds in cage which may be a result of higher metabolic activity due to physical movement.

\section{WBC count (WBC, $\left.10^{9} / \mathrm{l}\right)$}

Total white blood cell (WBC) counts and antibody production were significantly inhibited in hens in the heat stress group Mashaly et al., (2004). Higher WBC count in winter was obtained as compared to hothumid season which agrees with findings of 
Heller et al., (1979) who found that high environmental temperatures $\left(44.4\right.$ to $\left.47.8^{\circ} \mathrm{C}\right)$ suppress circulation of white blood cells (WBC). Datta et al., (1996) noticed similar increase in the amount of leucocytes in blood of ducks that were exposed to higher environmental temperature.

\section{Serum Biochemistry (Table 3 and 4)}

\section{Cholesterol (mg/dl)}

Present findings are in agreement with Panigrahy et al., (2017) who reported that no significant $(p>0.05)$ difference was observed in total cholesterol concentration between male and female in both seasons. During winter, cholesterol level was significantly higher than hot humid during 9 and 12 weeks.
Our findings are consistent with the report by Zulkifli et al., (1999) that stated serum concentration of cholesterol declined in response to heat stress.

\section{Glucose (mg/dl)}

Sex influenced glucose levels for 3 and 6 week old birds. Aseel female in litter during hot-humid had higher glucose levels than male. Blood glucose concentration increase may result from various stressors including heat stress (Borges et al., 2004). Our findings are consistent with the above report. Season affected glucose levels for age groups 3 and 6 weeks with winter recording lower values. Khan et al., (2002) reported that glucose levels increased in birds exposed to heat as compared to birds to birds in $28-32{ }^{\circ} \mathrm{C}$.

Table.1 Influence of season, breed, and sex and their interaction on haematology for age groups 3 and 6 week

\begin{tabular}{|c|c|c|c|c|c|c|c|}
\hline Effect & $\begin{array}{l}\text { TRBC } \\
\left(10^{6} / \mu \mathrm{l}\right)\end{array}$ & Hgb (g/dl) & $\operatorname{PCV}(\%)$ & $\operatorname{MCV}(\mathbf{f l})$ & MCH(pg) & $\operatorname{MCHC}(\mathrm{g} / \mathrm{dl})$ & $\operatorname{WBC}\left(10^{9} / l\right)$ \\
\hline \multicolumn{8}{|l|}{ Age effect } \\
\hline 3 week & $1.85 \pm 0.03$ & $13.31^{\mathrm{a}} \pm 0.30$ & $18.29 \pm 0.35$ & $102.45^{\mathrm{a}} \pm 0.32$ & $70.33^{\mathrm{a}} \pm 1.13$ & $69.37^{\mathrm{a}} \pm 1.10$ & $33.44 \pm 10.20$ \\
\hline 6 week & $1.88 \pm 0.02$ & $11.87^{\mathrm{b}} \pm 0.57$ & $18.68 \pm 0.22$ & $99.79^{\mathrm{b}} \pm 0.45$ & $59.72^{\mathrm{b}} \pm 0.60$ & $58.94^{\mathrm{b}} \pm 0.52$ & $20.23 \pm 0.16$ \\
\hline$P$-value & 0.485 & 0.025 & 0.346 & 0.000 & 0.000 & 0.000 & 0.196 \\
\hline \multicolumn{8}{|l|}{ Sex effect } \\
\hline Female & $1.87 \pm 0.03$ & $12.39 \pm 0.25$ & $18.94 \pm 0.28$ & $102.61^{\mathrm{a}} \pm 0.33$ & $65.01 \pm 0.93$ & $63.71 \pm 0.91$ & $21.20 \pm 0.15$ \\
\hline Male & $1.86 \pm 0.03$ & $12.78 \pm 0.60$ & $18.04 \pm 0.30$ & $99.63^{\mathrm{b}} \pm 0.44$ & $65.04 \pm 1.03$ & $64.60 \pm 0.95$ & $32.47 \pm 10.20$ \\
\hline P-value & 0.837 & 0.550 & 0.29 & 0.000 & 0.983 & 0.503 & 0.270 \\
\hline \multicolumn{8}{|l|}{ Breed effect } \\
\hline Aseel & $1.76^{\mathrm{b}} \pm 0.02$ & $11.92^{\mathrm{b}} \pm 0.21$ & $17.94^{\mathrm{b}} \pm 0.23$ & $102.74^{\mathrm{a}} \pm 0.40$ & $66.21 \pm 0.93$ & $64.49 \pm 0.95$ & $31.98 \pm 10.20$ \\
\hline Kadaknath & $1.98^{\mathrm{a}} \pm 0.03$ & $13.26^{\mathrm{a}} \pm 0.61$ & $19.03^{\mathrm{a}} \pm 0.33$ & $99.50^{\mathrm{b}} \pm 0.37$ & $63.84 \pm 1.02$ & $63.83 \pm 0.91$ & $21.69 \pm 0.19$ \\
\hline P-value & 0.000 & 0.039 & 0.008 & 0.000 & 0.086 & 0.618 & 0.314 \\
\hline \multicolumn{8}{|c|}{ Season effect } \\
\hline Hot -humid & $1.83 \pm 0.03$ & $14.26^{\mathrm{a}} \pm 0.61$ & $18.59 \pm 0.33$ & $102.55^{\mathrm{a}} \pm 0.49$ & $73.77^{\mathrm{a}} \pm 1.05$ & $72.29^{\mathrm{a}} \pm 1.02$ & $21.70 \pm 0.25$ \\
\hline Winter & $1.91 \pm 0.02$ & $10.92^{\mathrm{b}} \pm 0.14$ & $18.39 \pm 0.24$ & $99.69^{\mathrm{b}} \pm 0.24$ & $56.28^{\mathrm{b}} \pm 0.23$ & $56.02^{\mathrm{b}} \pm 0.21$ & $31.97 \pm 10.20$ \\
\hline P-value & 0.056 & 0.000 & 0.625 & 0.000 & 0.000 & 0.000 & 0.315 \\
\hline
\end{tabular}

Means within columns bearing different superscripts differ significantly $(\mathrm{p}<0.05)$ 
Table.2 Influence of season, breed, age, sex and rearing system and their interaction on hematology for age groups 9 and 12 week

\begin{tabular}{|c|c|c|c|c|c|c|c|}
\hline Effect & $\begin{array}{l}\text { TRBC } \\
\left(10^{6} / \mu \mathrm{l}\right)\end{array}$ & Hgb (g/dl) & $\operatorname{PCV}(\%)$ & $\operatorname{MCV}(\mathbf{f l})$ & MCH(pg) & $\operatorname{MCHC}(\mathrm{g} / \mathrm{dl})$ & $\operatorname{WBC}\left(10^{9} / \mathrm{l}\right)$ \\
\hline \multicolumn{8}{|l|}{ Age effect } \\
\hline $9^{\text {th }}$ week & $2.40 \pm 0.12$ & $12.40 \pm 0.19$ & $21.96 \pm 0.42$ & $99.57^{\mathrm{a}} \pm 0.42$ & $57.21 \pm 0.64$ & $59.16 \pm 0.64$ & $17.22 \pm 0.12$ \\
\hline $12^{\text {th }}$ week & $2.65 \pm 0.09$ & $12.59 \pm 0.17$ & $21.96 \pm 0.42$ & $97.48^{\mathrm{b}} \pm 0.40$ & $58.00 \pm 0.57$ & $61.12 \pm 0.60$ & $17.59 \pm 0.24$ \\
\hline$P$ - value & 0.089 & 0.659 & 0.182 & 0.000 & 0.354 & 0.028 & 0.166 \\
\hline \multicolumn{8}{|l|}{ Sex effect } \\
\hline Female & $2.60 \pm 0.13$ & $12.57 \pm 0.16$ & $21.11 \pm 0.26$ & $99.18^{\mathrm{a}} \pm 0.26$ & $58.23 \pm 0.61$ & $60.48 \pm 0.61$ & $17.38 \pm 0.19$ \\
\hline Male & $2.45 \pm 0.06$ & $12.50 \pm 0.20$ & $22.00 \pm 0.54$ & $97.87^{\mathrm{b}} \pm 0.50$ & $56.99 \pm 0.50$ & $60.40 \pm 0.68$ & $17.44 \pm 0.19$ \\
\hline P-value & 0.297 & 0.744 & 0.142 & 0.024 & 0.149 & 0.432 & 0.835 \\
\hline \multicolumn{8}{|l|}{ Breed effect } \\
\hline Aseel & $2.50 \pm 0.11$ & $12.48 \pm 0.15$ & $21.14 \pm 0.25$ & $100.08^{\mathrm{a}} \pm 0.49$ & $58.49^{\mathrm{a}} \pm 0.68$ & $60.86 \pm 0.76$ & $17.46 \pm 0.19$ \\
\hline Kadaknath & $2.55 \pm 0.10$ & $12.59 \pm 0.20$ & $22.00 \pm 0.54$ & $96.97^{\mathrm{b}} \pm 0.27$ & $56.73^{\mathrm{b}} \pm 0.52$ & $60.00 \pm 0.52$ & $17.36 \pm 0.18$ \\
\hline P-value & 0.767 & 0.624 & 0.137 & 0.000 & 0.040 & 0.807 & 0.699 \\
\hline \multicolumn{8}{|c|}{ Season effect } \\
\hline Hot -humid & $2.66 \pm 0.16$ & $13.04^{\mathrm{a}} \pm 0.23$ & $22.52^{\mathrm{a}} \pm 0.55$ & $97.07^{\mathrm{b}} \pm 0.51$ & $60.33^{\mathrm{a}} \pm 0.86$ & $65.36^{\mathrm{a}} \pm 0.77$ & $15.28^{\mathrm{b}} \pm 0.12$ \\
\hline Winter & $2.41 \pm 0.02$ & $11.84^{\mathrm{b}} \pm 0.10$ & $20.32^{\mathrm{b}} \pm 0.21$ & $100.36^{\mathrm{a}} \pm 0.18$ & $55.14^{\mathrm{b}} \pm 0.20$ & $55.50^{\mathrm{b}} \pm 0.21$ & $19.56^{\mathrm{a}} \pm 0.13$ \\
\hline P-value & 0.122 & 0.000 & 0.000 & 0.000 & 0.000 & 0.000 & 0.000 \\
\hline \multicolumn{8}{|c|}{ Rearing System effect } \\
\hline Cage & $2.35^{\mathrm{b}} \pm 0.03$ & $11.57^{\mathrm{b}} \pm 0.14$ & $21.75 \pm 0.24$ & $9950^{\mathrm{a}} \pm 0.45$ & $55.00^{\mathrm{b}} \pm 0.36$ & $57.32^{b} \pm 0.32$ & $17.50 \pm 0.18$ \\
\hline Litter & $2.70^{\mathrm{a}} \pm 0.14$ & $13.50^{\mathrm{a}} \pm 0.19$ & $21.37 \pm 0.55$ & $97.55^{\mathrm{b}} \pm 0.35$ & $60.21^{\mathrm{a}} \pm 0.74$ & $62.95^{\mathrm{a}} \pm 0.81$ & $17.32 \pm 0.19$ \\
\hline P-value & 0.017 & 0.000 & 0.531 & 0.001 & 0.000 & 0.000 & 0.482 \\
\hline
\end{tabular}

Means within columns bearing different superscripts differ significantly $(\mathrm{p}<0.05)$

Table.3 Influence of season, breed, and sex and their interaction on biochemistry for age groups 3 and 6 week

\begin{tabular}{|c|c|c|c|c|c|c|c|}
\hline Effect & $\begin{array}{c}\text { Cholesterol } \\
(\mathrm{mg} / \mathrm{dl})\end{array}$ & $\begin{array}{l}\text { Glucose } \\
\text { (mg/dl) }\end{array}$ & $\begin{array}{l}\text { Total Protein } \\
\text { (g/dl) }\end{array}$ & $\begin{array}{l}\text { Uric Acid } \\
\text { (mg/dl) }\end{array}$ & $\begin{array}{c}\text { Creatinine } \\
\text { (mg/dl) }\end{array}$ & $\begin{array}{c}\text { ALT } \\
\text { (IU/L) }\end{array}$ & AST(IU/L) \\
\hline \multicolumn{8}{|l|}{ Age effect } \\
\hline 3 week & $61.18^{\mathrm{b}} \pm 0.84$ & $279.64^{\mathrm{b}} \pm 1.47$ & $3.94 \pm 0.08$ & $4.58^{\mathrm{b}} \pm 0.04$ & $0.81 \pm 0.01$ & $4.74^{\mathrm{a}} \pm 0.10$ & $143.16 \pm 3.32$ \\
\hline 6 week & $79.94^{\mathrm{a}} \pm 1.61$ & $325.30^{\mathrm{a}} \pm 3.04$ & $3.71 \pm 0.03$ & $5.16^{\mathrm{a}} \pm 0.06$ & $0.82 \pm 0.01$ & $4.25^{\mathrm{b}} \pm 0.13$ & $139.09 \pm 1.56$ \\
\hline$P$ - value & 0.000 & 0.000 & 0.008 & 0.000 & 0.329 & 0.003 & 0.269 \\
\hline \multicolumn{8}{|l|}{ Sex -effect } \\
\hline Female & $68.93 \pm 1.47$ & $299.31 \pm 2.54$ & $3.83 \pm 0.07$ & $4.91 \pm 0.06$ & $0.82 \pm 0.01$ & $4.40 \pm 0.12$ & $142.55 \pm 2.85$ \\
\hline Male & $72.19 \pm 1.49$ & $305.63 \pm 3.38$ & $3.82 \pm 0.06$ & $4.82 \pm 0.05$ & $0.82 \pm 0.01$ & $4.58 \pm 0.11$ & $139.70 \pm 2.32$ \\
\hline $\mathbf{P}$-value & 0.121 & 0.136 & 0.843 & 0.249 & 0.906 & 0.281 & 0.438 \\
\hline \multicolumn{8}{|l|}{ Breed effect } \\
\hline Aseel & $75.28^{\mathrm{a}} \pm 1.60$ & $315.43^{\mathrm{a}} \pm 3.26$ & $3.81 \pm 0.05$ & $4.90 \pm 0.05$ & $0.85^{\mathrm{a}} \pm 0.01$ & $4.04^{\mathrm{b}} \pm 0.12$ & $144.22 \pm 2.66$ \\
\hline Kadaknath & $65.85^{\mathrm{b}} \pm 1.25$ & $289.51^{b} \pm 2.28$ & $3.84 \pm 0.08$ & $4.84 \pm 0.06$ & $0.78^{\mathrm{b}} \pm 0.01$ & $4.95^{\mathrm{a}} \pm 0.10$ & $138.03 \pm 2.52$ \\
\hline$P$-value & 0.000 & 0.000 & 0.716 & 0.489 & 0.000 & 0.000 & 0.092 \\
\hline \multicolumn{8}{|c|}{ Season effect } \\
\hline Hot -humid & $70.91 \pm 1.33$ & $314.02^{\mathrm{a}} \pm 3.63$ & $4.04^{\mathrm{a}} \pm 0.06$ & $4.50^{\mathrm{b}} \pm 0.04$ & $0.77^{b} \pm 0.01$ & $4.80^{\mathrm{a}} \pm 0.10$ & $155.14^{\mathrm{a}} \pm 2.18$ \\
\hline Winter & $70.21 \pm 1.62$ & $290.92^{b} \pm 1.77$ & $3.61^{b} \pm 0.06$ & $5.24^{\mathrm{a}} \pm 0.05$ & $0.87^{\mathrm{a}} \pm 0.01$ & $4.19^{b} \pm 0.13$ & $127.11^{\mathrm{b}} \pm 2.51$ \\
\hline$P$-value & 0.739 & 0.000 & 0.000 & 0.000 & 0.000 & 0.000 & 0.000 \\
\hline
\end{tabular}

Means within columns bearing different superscripts differ significantly $(\mathrm{p}<0.05)$ 
Table.4 Influence of season, breed, age, sex and rearing system and their interaction on biochemistry 9 and 12 weeks for age groups $9^{\text {th }}$ and $12^{\text {th }}$ week

\begin{tabular}{|l|l|l|l|l|l|l|l|}
\hline Effect & $\begin{array}{l}\text { Cholesterol } \\
(\mathbf{m g} / \mathbf{d l})\end{array}$ & $\begin{array}{l}\text { Glucose } \\
(\mathbf{m g} / \mathbf{d l})\end{array}$ & $\begin{array}{l}\text { Total } \\
\text { Protein } \\
(\mathbf{g} / \mathbf{d l})\end{array}$ & $\begin{array}{l}\text { Uric Acid } \\
(\mathbf{m g} / \mathbf{d l})\end{array}$ & $\begin{array}{l}\text { Creatinine } \\
(\mathbf{m g} / \mathbf{d l})\end{array}$ & ALT (IU/L) & AST(IU/L) \\
\hline Age effect & & \multicolumn{7}{|l|}{} & & & \\
\hline $\mathbf{9}^{\text {th }}$ week & $104.77 \pm 1.97$ & $364.20^{\mathrm{b}} \pm 1.51$ & $2.98^{\mathrm{b}} \pm 0.10$ & $5.25^{\mathrm{a}} \pm 0.09$ & $0.81^{\mathrm{a}} \pm 0.01$ & $3.16 \pm 0.18$ & $119.30^{\mathrm{b}} \pm 1.70$ \\
\hline $\mathbf{1 2}^{\text {th }}$ week & $104.32 \pm 1.74$ & $379.60^{\mathrm{a}} \pm 4.88$ & $4.20^{\mathrm{a}} \pm 0.03$ & $4.05^{\mathrm{b}} \pm 0.04$ & $0.71^{\mathrm{b}} \pm 0.04$ & $6.13 \pm 0.22$ & $155.12^{\mathrm{a}} \pm 3.72$ \\
\hline P- value & 0.862 & 0.003 & 0.000 & 0.000 & 0.008 & 0.202 & 0.003 \\
\hline Sex effect & & & & & & \\
\hline Female & $106.04 \pm 1.85$ & $372.57 \pm 3.78$ & $3.59 \pm 0.07$ & $4.62 \pm 0.08$ & $0.77 \pm 0.03$ & $4.74 \pm 0.20$ & $134.54 \pm 2.83$ \\
\hline Male & $103.05 \pm 1.85$ & $371.22 \pm 3.50$ & $3.59 \pm 0.10$ & $4.67 \pm 0.08$ & $0.75 \pm 0.02$ & $4.54 \pm 0.26$ & $139.87 \pm 3.56$ \\
\hline P-value & 0.253 & 0.794 & 0.975 & 0.637 & 0.431 & 0.542 & 0.241 \\
\hline Breed effect & & & & & & & \\
\hline Aseel & $108.93^{\mathrm{a}} \pm 1.77$ & $366.37^{\mathrm{b}} \pm 2.75$ & $3.49 \pm 0.07$ & $4.46^{\mathrm{b}} \pm 0.07$ & $0.74 \pm 0.01$ & $4.55 \pm 0.19$ & $132.19 \pm 2.41$ \\
\hline Kadaknath & $100.16^{\mathrm{b}} \pm 1.89$ & $377.24^{\mathrm{a}} \pm .33$ & $3.69 \pm 0.10$ & $4.84^{\mathrm{a}} \pm 0.08$ & $0.79 \pm 0.04$ & $4.74 \pm 0.27$ & $142.23 \pm 3.83$ \\
\hline P-value & 0.001 & 0.032 & 0.8 & 0.001 & 0.167 & 0.564 & 0.27 \\
\hline Season effect & & & & & & \\
\hline Hot - -humid & $92.31^{\mathrm{b}} \pm 1.37$ & $410.11 \pm 3.25$ & $3.85^{\mathrm{a}} \pm 0.02$ & $4.14^{\mathrm{b}} \pm 0.03$ & $0.68^{\mathrm{b}} \pm 0.03$ & $3.16^{\mathrm{b}} \pm 0.18$ & $119.30^{\mathrm{b}} \pm 1.70$ \\
\hline Winter & $116.78^{\mathrm{a}} \pm 1.94$ & $333.68 \pm 1.95$ & $3.33^{\mathrm{b}} \pm 0.11$ & $5.15^{\mathrm{a}} \pm 0.10$ & $0.84^{\mathrm{a}} \pm 0.03$ & $6.13^{\mathrm{a}} \pm 0.22$ & $155.12^{\mathrm{a}} \pm 3.72$ \\
\hline P-value & 00.000 & 0.300 & 0.000 & 0.000 & 0.000 & 0.000 & 0.000 \\
\hline Rearing system effect & & & & & & \\
\hline Cage & $104.45 \pm 1.81$ & $370.10 \pm 4.09$ & $3.71^{\mathrm{a}} \pm 0.10$ & $4.38^{\mathrm{b}} \pm 0.08$ & $0.79 \pm 0.04$ & $4.86 \pm 0.22$ & $139.38 \pm 3.63$ \\
\hline Litter & $104.64 \pm 1.89$ & $373.70 \pm 3.14$ & $3.47^{\mathrm{b}} \pm 0.06$ & $4.92^{\mathrm{a}} \pm 0.08$ & $0.74 \pm 0.01$ & $4.43 \pm 0.24$ & $135.03 \pm 2.74$ \\
\hline P-value & 0.941 & 0.485 & 0.04 & 0.000 & 0.205 & 0.197 & 0.339 \\
\hline
\end{tabular}

Means within columns bearing different superscripts differ significantly $(\mathrm{p}<0.05)$

\section{Total Protein (g/dl)}

Total protein values were remained unaffected by sex in our study which is in contrary to Abdi-Hachesoo (2013) who reported total protein concentration for 18 week old adults as $3.87 \mathrm{~g} / \mathrm{dl}$ in males and 5.22 $\mathrm{g} / \mathrm{dl}$ in females, respectively. In the present study, total protein values were more in older birds which in agreement to Schmidt et al., (2007). The total protein values were ranging between $2.66 \pm 0.05$ to $5.30 \pm 0.12$ in both the seasons. In hot -humid season, the values were higher $(\mathrm{P}<0.05)$ than in winter season, it may be due to Hot -humid stress which is in agreement with the result of Aarif et al (2014).

\section{Uric Acid (mg/dl)}

Uric acid value for Aseel male reported by Kumar and Kumbhkar et al., (2015) as $5.23 \pm 0.15 \mathrm{mg} / \mathrm{dL}$ is falling in range of $3.33 \pm 0.03-6.47 \pm 0.06$ reported during present study. Uric acid for male and female was $4.67 \pm 0.08$ and $4.62 \pm 0.08$ which is lower than values reported by Pampori and Iqbal (2007) as $6.31 \pm 0.33$ and $6.21 \pm 0.40$ for male and female in Kashmiri chicken, respectively.

Uric acid values were significantly affected by breed in age groups 9 and 12 weeks with Kadaknath recording higher values. Uric acid values for adult Aseel (4.46 \pm 0.07$)$ and Kadaknath (4.84 \pm 0.08$)$ reported during 
present experiment are comparable to range (4.16-4.63 mg/dL) determined by Bhatti et al., (2001) for Desi and Naked Neck hens. Age and diet may influence the concentration of blood uric in birds.

\section{Creatinine (mg/dl)}

Researchers have used creatinine as an indicator of muscle metabolism but this remains to be confirmed (Bowes et al., 1989). Creatinine value recorded for 9 and 12 weeks was $0.79 \pm 0.04$ in Kadaknath and $0.74 \pm 0.01$ $\mathrm{mg} / \mathrm{dl}$ in Aseel which is lower than values of $0.95 \mathrm{mg} / \mathrm{dl}$ reported by Ladokun et al., (2008) for Nigerian naked neck. Significant difference was observed between values of $9^{\text {th }}$ week and $12^{\text {th }}$ week. This is similar to a study (Polat et al., 2011) in which creatinine levels varied significantly in broiler chickens due to diet.

\section{ALT and AST (IU/L)}

The values of ALT and AST in chicken are 5$15 \mathrm{U} / \mathrm{L}$ and $174.8 \mathrm{U} / \mathrm{L}$, respectively (Kaneko, 2008).The ALT and AST enzyme concentration were significantly $(p<0.05)$ higher in Hot -humid than winter. Reports of present study are consistent with Panigrahy et al., (2017) who reported no significant ( $p>0.05)$ differences were observed in ALT and AST enzyme concentration between male and female. Abdi-Hachesoo et al., (2013) observed ALT as $7.80 \pm 1.62$ in male and $7.20 \pm 1.47$ in females of indigenous birds.

From this study it may be concluded that interactive effects of age, sex, season and rearing system may affect hematobiochemical parameters in birds. Age wise baseline hemato-biochemical data for Aseel and Kadaknath for hot-humid and winter season under cage and deep litter rearing system have been recorded.

\section{Statement of Animal Rights}

The study was carried out as per the guidelines and approval of institute animal ethical committee (IAEC) and committee for the purpose of control and supervision of experiments on animals (CPCSEA).

\section{Conflict of interest}

The authors declare that they have no competing interests.

\section{References}

Aarif, O., Shergojry, S.A., Dar, S.A., Khan, N., Mir, N.A. and Sheikh, A.A. 2014.Impact of cold stress on blood biochemical and immune status in male and female Vanaraja chickens. Indian Journal. Of Animal Research., 48(2): 139-142.

Abdi-Hachesoo, B., Talebi, A., Asri-Rezaei, S., and Basaki, M.,2013. Sex related differences in biochemical and hematological parameters of adult indigenous chickens in Northwest of Iranian Journals of Animal Science Advances. 3(10): 512-516.

Addass, P.A., David, D.L., Edward, A., Zira and Midau, K. E., 2012. A Effect of Age, Sex and Management System on Some Haematological Parameters of Intensively and Semi- Intensively Kept Chicken in Mubi, Adamawa State, Nigeria. Iranian Journal. Applied Animal Science 2(3): 277-282.

Bhatti,B. M., Talat, T. and Sardar, R. 2001. Glucose, total proteins, uric acid and triglycerides concentrations in blood of native laying hens, in Desi and Naked Neck hens. Pakistan Veterinary Journal, 21: 222-223.

Bowes, V. A., Julian, R. J., and Stirtzinger, T. 1989. Comparison of serum biochemical profiles of male broilers 
with female broilers and White Leghorn chickens. Canadian Journal of Veterinary Research., 53(1), 7.

Datta C., Roy, S., Ghosh S.P., Roy B.N., Bhattacharya B.1996: Effect of different ambient temperature on some physiological, haematological and biochemical characteristics of Desi and Khaki Campbell. Indian Journal of Animal Health, 35, 169-174

Donkoh, A. 1989. Ambient temperature: a factor affecting performance and physiological response of broiler chickens. International Journal of Biometeorology.33(4): 259-265.

Dos Santos Schmidt, E. M., Paulillo, A. C., Santin, E., Dittrich, R. L., and De Oliveira, E. G. 2007. Hematological and serum chemistry values for the ring-necked pheasant (Phasianus colchicus): variation with sex and age. International Journal of Poultry Science. 6(2): 137-139.

Hawkey, C., Hart, M. G., Samour, H. J., knight, J. A. and Hutton R. E. 1984.Haematological findings in healthy and sick captive Rosy flamingos (Phoenicoptus ruberruber). Avian Pathology. 13: 163-172.

Hawkey, C., Samour, J. H., Ashton, D. G., Hart, M. G., Cindery, B. N., Finch, J. M. And Jones, D. M. 1983: Normal and clinical haematology of captive cranes (Gruiforms). Avian Pathology.12: 7384.

Heller, E. D., Nathan, D. B., \&Perek, M. 1979.Short heat stress as an immunostimulant in chicks. Avian Pathology., 8(3), 195-203.

Hussain, M., Mahmud, A., Hussain, J., Qaisrani, S. N., Mehmood, S., Ahmad, S., and Rehman, A. U. (2018). Effect of dietary amino acid regimens on growth performance and body conformation and immune responses in Aseel chicken. Indian Journal of Animal
Research.1-6

Islam, M. S., Lucky, N. S., Islam, M. R., Ahad, A., Das, B. R., Rahman, M. M., and Siddiui, M. S. I. 2004. Haematological parameters of Fayoumi, Assil and local chickens reared in Sylhet region in Bangladesh. International Journal of Poultry Science 3(2): 144-147.

Julian, R. J., McMillan, I., and Quinton, M.,1989. The effect of cold and dietary energy on right ventricular hypertrophy, right ventricular failure and ascites in meat- type chickens. Avian Pathology.18(4): 675-684.

Kaneko, J. J., Harvey, J. W., and Bruss, M. L. (Eds.). 2008. Clinical biochemistry of domestic animals. Academic press.

Kaushish, S. K., Bhatia, D. C. and Arora, K. L. 1976. Studies on adaptability of sheep to sub-tropical climate and seasonal changes in rectal temperature, cardio-respiratory and haematological attributes of Nali sheep. Indian Veterinary Journal. 53: 760-765.

Khan, W. A., Khan, A., Anjum, A. D. and Rehman, Z. 2002. Effects of induced heat stress on some biochemical values in broiler chicks. International Journal of Agriculture and Biology. 4(1).

Kumar B and, Kumbhakar N. B. Haematobiochemical profile of Aseel in Chhattisgarh region. Indian Veterinary Journal. 2015; 92(1):40-42.

Kundu, A. K., Kundu, M. S., Sunder, J., Jeyakumr, S., and Sujatha, T, 2015. Production performance of indigenous Nicobari fowls, Vanaraja and their various F1 crosses under hot and humid climate of Andaman and Nicobar Islands, India. Indian Journal of Animal Science., 85(2): 172-177

Ladokun, A. O., Yakubu, A., Otite, J. R., Omeje, J. N., Sokunbi, O. A., and Onyeji, E., 2008. Haematological and serum biochemical indices of naked 
neck and normally feathered Nigerian indigenous chickens in a sub humid tropical environment. International Journal Poultry Science. 7(1): 55-58.

Mashaly, M. M., Hendricks, G. L., Gelad, A. E., Abbas, A.O. and Patterson, P. H. 2004.Effect of heat stress on production parameters and immune responses of commercial laying hens. Poultry Science.83 (6): 889-894.

Olayemi, F. O., and Arowolo, R. O. A., 2009. Seasonal variations in the haematological values of the Nigerian duck (Anasplatyrhynchos). International Journal of Poultry Science.8(8), 813-815.

Pampori, Z. A., and Saleem Iqbal, 2007. Haematology, serum chemistry and electrocardiographic evaluation in native chicken of Kashmir. International Journal of Poultry Science. 6, no. 8: 578-582.

Pandian, C., Thangapandiyan, M., Omprakash, A. V., Thyagarajan, D., and Babu, M., 2012. Effect of season on haematological profile and erythrocyte indices in White Leghorn layers. Tamil J Vet AnimSci, 8, 389392. Poultry Science. 83:765-775.

Panigrahy, K. K., Behera, K., Mohapatra, L. M., Acharya, A. P., Sethy, K., Panda, S., and Gupta, S. K. (2017). Sex-related differences in hemato-biochemical indices of adult Vanaraja chickens during summer and winter seasons. Veterinary World, 10(2), 176

Polat, U., Yesilbag, D., and Eren, M. 2011. Serum biochemical profile of broiler chickens fed diets containing rosemary and rosemary volatile oil. Journal of Biological and Environmental Science., 5(13).

Tibbo, M., 2008. Serum enzymes levels and influencing factors in three indigenous Ethiopian goat breeds. Tropical Animal health and production. 40.8 (): 657666.

Tyagi, J. S., Singh, R. A., Sharma, R. K. and Sharma, P. K., 2007. Effect of saline drinking water simulated on pattern of underground water on haematology of broiler chicks. Indian Journal of Poultry Science.42: 37-42

Yahav, S. and Hurwitz, S. 1996.Induction of thermotolerance in male broiler chickens by temperature conditioning at an early age. Poultry Science.75: 402406.

Zulkifli, I., Dass, R. T., and Norma, M. C., 1999. Acute heat-stress effects on physiology and fear-related behaviour in red jungle fowl and domestic fowl. Canadian Journal of Animal Science., 79(2), 165-170.

Zhang, H., Wu, C. X., Chamba, Y., and Ling, Y., 2007. Blood characteristics for high altitude adaptation in Tibetan chickens. Poultry Science., 86(7), 13841389.

\section{How to cite this article:}

Shanmathy, M., J. S. Tyagi, M. Gopi, J. Mohan and Beulah, P. 2020. Effect of Various Factors on Hematology and Serum Biochemistry Values of Aseel and Kadaknath Chicken. Int.J.Curr.Microbiol.App.Sci. 9(08): 1695-1703. doi: https://doi.org/10.20546/ijcmas.2020.908.195 